2. Dontsov, D. (1953). The anxiety for the heroic. London [in Ukrainian].

3. Druskin, M. (1970). Johannes Brahms. Muzyka, Moskva [in Russian].

4. Mihaylov, M. (1990), "On the classicist tendencies in the music of the nineteenth - early twentieth century", Etudes about style in music, Muzyka, Leningrad [in Russian]

5. Moskalenko, V. (1979). "Za dirizherskim pul'tom", Sovetskaya muzyka, no.12, [in Russian].

6. Rozhok, V. (2006). Sunshine Maestro. Kyiv: Avtograf [in Ukrainian].

7. Rozhok, V. (1994). Stefan Turchak. Harkiv [in Ukrainian].

8. Chyzhevskyi, D. (1991). Essays on the history of philosophy in Ukraine. New York [in Ukrainian]. Russian].

9. Careva, E. (1971). To the problem of Johannes Brahms style. From the history of foreign music. Moskva: Muzsika [in

10. Sherekh (Shevelov), Yu (1993), Etudes about national in the literature of the present. Suchasnist, 1, 76-85 [in Ukrainian].

Стаття надійшла до редакції 18.09.2018 p.

UDC [908:82]:929(045)

\author{
Kachur Myroslava \\ Candidate of Pedagogical Sciences \\ Associate Professor, \\ Head of the Department of Singing, \\ Conducting and Musical and Theoretical Disciplines, \\ Mukachevo State University \\ ORCID 0000-0002-9311-5741 \\ mkachyr17@gmail.com \\ Mykulanynets Lesya \\ Candidate of Art Studies, \\ Senior Lecturer at the Department of Singing, \\ Conducting and Musical and Theoretical Disciplines, \\ Mukachevo State University \\ ORCID 0000-0002-6346-6532 \\ I.mikulaninets@gmail.com
}

\title{
BIOGRAPHICAL APPROACH IN THE DISCOURSE OF ARTISTIC COUNTRY STUDIES
}

The purpose of the article is to specify the essence of the biographical approach, to reveal its role in interpreting material and spiritual achievements of the mankind and to establish its significance in the discourse of artistic country studies on the basis of thorough analysis and summary of the works in the spheres of sociology, culture and art studies. Methodology of the research consists in implementation of analytical, culturological, historical, axiological and systematic methods in order to reveal the sense of the biographical approach in the discourse of artistic country studies. Scientific novelty. The authors of the article specify the essence of the biographical approach, provide arguments in favour of its efficiency in culture interpretation and substantiate its importance for realizing the achievements of artistic country studies. Conclusions. Analysis of the works dedicated to the issue of biographical approach enabled the authors to ascertain that it is a specific scientific trend aimed at the study of anthropological processes, the basis of which is the ontological chronicle of a particular person, projection of their inner world, methodology of studying personal experience and fixation of this experience in history with the purpose to understand the very essence of the civilization. The direct object of the approach mentioned above is the description of an individual's life and creative functioning from the moment of birth to death, and its subject is a social and artistic situation that gives certain meaning and ideological wholeness to human existence. Chronicle is a portrait of the epoch, which reveals conceptual principles of certain age. Highlighting the world outlook of a creative personality, the biographical approach interprets the person's existential ideas, discovers their relations to the events of social and political life, as well as material and spiritual achievements of the mankind. Paying attention to the major events in the chronicle of an artist, modern art studies reconstruct and interpret the sense of the previous epochs and helps to find the sense of the person's life. Biographical approach as a way to study the artistic culture of the region promotes discovery of the peculiarities of its development within certain period, finding the ways to transform material and spiritual spheres and acknowledgement of the postulate that history is created by people and the process of art formation in the region depends on activities of its prominent figures.

Key words: chronicle; biographical approach; artist; artistic country studies.

Качур Мирослава Михайлівна, кандидат педагогічних наук, доцент, завідувач кафедри співу, диригування і музично-теоретичних дисциплін Мукачівського державного університету; Микуланинець Леся Михайлівна, кандидат мистецтвознавства, старший викладач кафедри співу, диригування і музично-теоретичних дисциплін Мукачівського державного університету

Біографічний підхід у дискурсі художнього краєзнавства

Мета роботи - на основі аналізу та узагальнення праць у галузі соціології, культурології, мистецтвознавства уточнити сутність біографічного підходу, розкрити його роль в інтерпретації матеріальних і духовних досягнень людства, виявити значення у дискурсі художнього краєзнавства. Методологія дослідження полягає у застосуванні аналітичного, культурологічного, історичного, аксіологічного та системного методів для розкриття смислу біографічного підходу в дискурсі художнього краєзнавства. Наукова новизна. У статті уточнено сутність біографічного підходу, аргументовано думку, що він $є$ дієвим в інтерпретації культури, обґрунтовано його значення у розумінні здобутків художнього краєзнавства. Висновки. Аналіз праць, присвячених проблемі біографічного підходу, дозволив констатувати, що це особливий науковий напрям дослідження антропологічних процесів, в основі якого $є$ онтологія літопису конкретної персони, відтворення її внутрішнього світу, методологія вивчення й фіксації особистого досвіду в історії з метою розуміння змісту цивілізації. Безпосереднім об'єктом вищезазначеного підходу є опис життя і

(C) Kachur M., 2019

(C) Mykulanynets L., 2019 
творчого функціонування індивідуума від моменту народження до смерті, а предметом - соціальна і мистецька ситуація, яка надає буттю сутнісне значення й ідейну цілісність. Життєпис - це портрет епохи, який розкриває концептуальні засади певної доби. Висвітлюючи світоглядні норми креативної особистості, біографічний підхід інтерпретує ідеї буття суб'єкта, виявляє його взаємовідносини з подіями суспільного і політичного побутування, матеріальними та духовними здобутками людства. Звертаючись до основних засад літопису митця, сучасне мистецтвознавство реконструює та тлумачить смисл попередніх епох, допомагає знайти сенс існування персони. Біографічний підхід як спосіб вивчення художньої культури регіону сприяє розкриттю особливостей його розвитку в конкретний період, виявленню шляхів трансформації матеріальної і духовної сфрери, усвідомленню постулату, що історію творять особистості, а процес формування мистецтва краю залежить від діяльності його визначних діячів. Ключові слова: життєпис; біографрічний підхід; митець; художнє краєзнавство.

Качур Мирослава Михайловна, кандидат педагогических наук, доцент, заведующая кафедрой пения, дирижирования и музыкально-теоретических дисциплин Мукачевского государственного университета; Микуланинец Леся Михайловна, кандидат искусствоведения, старший преподаватель кафедры пения, дирижирования и музыкально-теоретических дисциплин Мукачевского государственного университета

Биографический подход в дискурсе художественного краеведения

Цель работы - на основе анализа и обобщения работ в области социологии, культурологии, искусствоведения уточнить сущность биографического подхода, раскрыть его роль в интерпретации материальных и духовных достижений человечества, выявить значение в дискурсе художественного краеведения. Методология исследования заключается в применении аналитического, культурологического, исторического, аксиологического и системного методов для раскрытия смысла биографрического подхода в дискурсе художественного краеведения. Научная новизна. В статье уточнена сущность биографического подхода, аргументировано мнение, что он является действенным в интерпретации культуры, обосновано его значение в понимании достижений художественного краеведения. Выводы. Анализ работ, посвященных проблеме биографического подхода, позволил констатировать, что это особое научное направление исследования антропологических процессов, в основе которого лежит онтология летописи конкретной персоны, воспроизведение ее внутреннего мира, методология изучения и фриксации личного опыта в истории с целью понимания смысла цивилизации. Непосредственным объектом вышеупомянутого подхода является описание жизни и творческого функционирования индивидуума от момента рождения до смерти, а предметом - социальная и художественная ситуация, которая предоставляет бытию сущностное значение и идейную целостность. Жизнеописание это портрет эпохи, который раскрывает ее концептуальные основы. Освещая мировоззренческие нормы креативной личности, биографический подход интерпретирует идеи бытия субъекта, обнаруживает его взаимоотношения с событиями общественной и политической жизни, материальными и духовными достижениями человечества. Обращаясь к принципами летописи художника, современное искусствоведение реконструирует и объясняет сущность предыдущих эпох, помогает найти смысл существования персоны. Биографический подход как способ изучения художественной культуры региона способствует раскрытию особенностей его развития в конкретный период, выявлению путей трансформации материальной и духовной сферы, осознанию постулата, что историю создают личности, а процесс формирования искусства края зависит от деятельности его выдающихся представителей.

Ключевые слова: жизнеописание; биографический подход; художник; художественное краеведение.

Actuality of the research issue. Modern social and cultural conditions are characterized by an increased interest to the biographical aspect as one of the dominant in art interpretation. Supposedly, the issue of human life analysis occupies the leading position within the system of humanitarian sciences. This issue is fundamental in psychology, sociology, pedagogics, culturology, art studies etc. In particular, the analysis of an artistic person's life is extremely relevant, as such a person represents the most typical characteristic features if his or her epoch.

Analysis of recent researches and publications. Scientists turn to elucidation of a distinguished person's life experience being fully aware of the fact that in such a way they can find the answers to not only historical but also current questions. The biographical genre was studied in its various aspects by foreign (Charlotte Bühler, J. Levy, Charles de Sainte-Beuveas, V. Teyer) as well as Ukrainian scholars (I. Akinshyna, O. Valevskiy, T. Yemelianova, L.Levchuk, H. Makarenko, L. Mykulanynets, O. Onishchenko, T. Rosul, I.Savenko, T. Cherkashyna etc).

Nowadays national art studies more and more often discover the integrity of the creative person's life and cultural processes. Scientists highlight the life of an individual in the following contexts: social phenomenon (I. Holubovych), social and cultural perspective of history (S. Ikonnykova, T.Rosul), means of interpreting artistic individuality (T. Yemelianova, L. Mykulanynets), cultural and aesthetic issue (O.Kryvtsun), phenomenon and object of culture (O.Popovych) etc.

The study of the chronicles as well as the analysis of the links between the life history of an artist and his achievements are gaining more attention among the adherents of the biographical approach, the sense of which is to investigate the essence of the human civilization. As a result of its application, the object of the study is the personality in the aspect of spiritual and material achievements of the country or its region. Discovery of mental features of the ethnos, determination of typical characteristics of life on certain territory within certain historical period and recognition of the achievements of professional and folk arts are the tasks that are set forth in front of the artistic culture studies. One of the ways to cope successfully with the them can be implementation of of the approach mentioned above.

The purpose of the research is to specify the essence of the biographical approach, to reveal its role in interpreting material and spiritual achievements of the mankind and to establish its significance in the discourse of artistic country studies on the basis of thorough analysis and summary of the works in the spheres of sociology, culture and art studies.

Layout of the main material. Since ancient times study of a person's life chronicle has been the object of investigation for scientists. Using it as the major source of knowledge was a characteristic feature of the Chinese and Greek philosophies. Prominent figures of the civilizations mentioned above understood history as a summation of individual chronicles, which add personal characteristics to social and cultural materi- 
al. The work of ancient thinker Plutarch "Parallel lives" was considered the standard of biographical written genre up to XIX century. It allowed the genre to gain the status of a serious work with significant scientific content.

In European humanitarian sciences the interest to artistic course of life as a document that is a testimony of certain time can be observed in the Middle Ages. At that time there was formed the genre of literary memoirs, which was characterized by the synthesis of mass affordability and high artistic level. It is due to publishing chronicles of famous people that the public got acquainted with the most significant processes of various epochs, artistic trends and their representatives. However, biographical approach reached its peak at the turn of XIX - XX centuries, which was preconditioned by the change of cultural paradigm, social and economic instability, and search for historical experience that could facilitate solving relevant existential problems of those times.

Within the period mentioned above there was a vivid tendency to consider the two phenomena - "biography" and "life" - identical. In sharp contrast to rationalistic philosophy, W. Dilthey, F. Nietzsche, A.Bergson, O.Spengler and other philosophers considered the existence of a person to be the primary reality, with which it is entwined through numerous links.

The XX century is marked by the development of the so called scientific biography. It is explicated as a separate kind of research combining historical investigation and unique form of literature and being a part of the spiritual heritage of the mankind. Its purpose was reconstruction of certain epoch as well as the image of certain individual integrated in it. Simultaneously, life chronicles are implied to be the organic component of culture, i.e. its artistic, communicative, scientific and intellectual aspects.

Modern humanitarian science is characterized by activation of polemics concerning the significant role of chronicles of outstanding people's lives in realizing artistic work and its social functions. It contributes to gradual formation of biographical science as a separate branch of art and culture scientific research. This tendency is based on the views of French scientist Charles de Sainte-Beuveas (1804 - 1869), who considered that it is impossible to analyze the content of a literary work without studying the life path of the author.

It is worth mentioning that in numerous works connected with the issue of creative life experience of a person, definitions "biographical method" and "biographical approach" are used as synonyms, which gives evidence of relative novelty of the biographical science as well as insufficient development of its methodological base.

I.Holubovych considers that the biographical approach "fixates the direction of research interest, which is targeted at the range of problems referring to chronicles in their multifaceted manifestation: as a social and cultural phenomenon, as a literary and scientific genre, a set of means to analyze biographical (autobiographical) material in different branches of humanities etc." [3, 95]. In other words, with its help it is possible to reconstruct the full picture of the person's main life stages (through study of the maximal number of sources), to reproduce the specificity of the author's formation and evolution, to cover the link between creative achievements resulted from his/her activities and the processes of social and artistic life of certain epoch, country or region.

Sociologist H. Soloviov determines the approach mentioned above in the following way: "a research strategy, which includes a combination of methods and techniques enabling a researcher to obtain certain information about a person, conditions of his or her life and determinants of his or her functioning" [8, 1547]. This thought can be interpreted as a peculiar program aimed at developing and correcting a person's style of behavior, which id connected with the development of life-building skills. Having applied this tactics practically, a scientist gains maximal amount of knowledge, which might enable him to understand a person and his or her deeds to a great extent.

In culturology many theoreticians (Y. Bespalova, S. Ikonnykov,V, Liakh, N. Manzhelevska, D. Sihida and others) interpret the biographical approach as a dominant one in analysis of the socio-cultural environment where life and activity of a person takes place, his or her uniqueness is formed and creative fulfillment occurs. The scientist postulate that it is human talent that gives possibility for the civilization to progress, transform the character of values accepted in society, correct relationships between individuals and be the driving force behind social processes $[1 ; 2 ; 4 ; 5]$.

Art critics (I. Holubovych, L. Mykulanynets, T.Rosul etc.) explicate the approach under investigation as a peculiar kind of scientific cognition in which a dialogue between a person, culture and society is presented; correlation between internal impulses of a subject and the needs of his country (or region) are reconstructed with the purpose of personified perception and transformation of the civilization [3; 7].

Admittedly, the approach mentioned above is interpreted in culture and art studies wider than in sociological science, as its implementation not only facilitates understanding the individual himself/herself, their deeds and peculiarities of their coexistence with other people, but also shows the essence of creative activity and its role in formation of spiritual and material component of homo sapiens.

Thus, we can state that the biographical approach is a complex recreation of an artist's life path from the positions of psychological, social and artistic existence; discovery of its significance for historical and socio-cultural phenomena of the country. In terms of its sense, it is anthropocentric, as existence of certain epoch and its achievements are interpreted through the personality of the artist. Philosophic comprehension of the approach mentioned above allows developing the theory of personality. 
However, the subject's chronicle is also a social vertical demonstrating functioning of certain nation, its achievements in all the spheres, it is a link between different periods which enables the researcher to investigate the time, work and character. Not only is it a historical excursus, but also immersion into a specific continuum of civilization, understanding its laws and specificity of its evolution.

Y. Lotman stated that reconstruction of an individual's life in the form of a narrative is "the archeology of culture". We are well aware of the fact that a creative person performs a specific mission; he/she acts as an intermediary in large-scale universal processes as well as social and historical events in the country of residence. Therefore, personal chronicles become the exponent of complexity and controversy of social life.

Personal biography fixates socio-cultural situation of the epoch. On the one hand, its achievements demonstrate talent, but on the other hand, show artistic and political events. Life chronicle is an important tool to explicate the dynamics of actions in material and spiritual spheres of humanity through the prism of personal experience of a creative subject. Such information is extremely meaningful at crucial points, when new styles, directions or trends are being conceived.

A significant potential of the biographical approach can be discovered within the frames of artistic country studies, the purpose of which is the study of historical and cultural processes and phenomena on certain territory in the context where there exist internal horizons of personality, their ethic and esthetic norms and world-view principles. Application of its foundations facilitates resistance to globalization by means of profound cognition of the rich spectrum of the national and regional artistic specificity. Artistic country studies allows for comprehending and systemizing specific ethnic achievements from the position of modern scientific methodology.

Existence of material and spiritual achievements of certain geographical space is preconditioned by functioning of the person living on this territory. Simultaneously, artistic phenomena are derivatives from individual subjectivity of artists and their personal perception of the sense of regional culture. A creative personality, being formed in local social ground, represents it through creation of artistic images.

In this dimension the life path of the author of an artistic text should be considered the foothold in understanding the achievements of the land. It exists in dialectal unity of two components: impact of specific territory and its material and spiritual heritage on the outlook of an artist; influence of his/her personal activity on socio-cultural life of his/her native land. In artistic country studies the chronicles of a subject are explicated as simultaneous reflection of individual and collective concept of certain region, mental features of its ethnos, which are manifested in a creative product. Therefore, application of the biographical approach in the discourse of artistic country studies opens wide perspectives to comprehend local culture and to establish its significance in the nationwide context.

Conclusions: analysis of the works dedicated to the issue of the biographical approach enabled the authors to state that it is a specific scientific trend in investigating anthropological processes, in the basis of which there is ontology of life chronicles of certain person, reflection of their inner world, methodology of study and fixation in history with the purpose to comprehend the sense of civilization. The direct object of the approach mentioned above is description of life and artistic functioning of an individual from the very birth till death, whereas its subject is the social and artistic situation which provides meaningful existence and ideological integrity.

Life chronicle is a portrait of the epoch, which reveals the conceptual basis of certain age. Discovering world-view norms of a creative personality, the biographical approach interprets ideas of person's existence, uncovers their interconnections with the events of social and political life as well as material and spiritual achievements of the mankind. Taking into account the fundamentals of the artist's chronicles, modern artistic study reconstructs and interprets the sense of the previous epochs and helps to discover the sense of person's existence.

The biographical approach as a way to study the artistic culture of the region facilitates discovery of peculiarities of its development within certain period, finding the ways of material and cultural transformation as well as realizing the postulate that history is created by people and the process of art formation in the region depends on activities of its prominent artists.

The article does not settle all the aspects of the issue declared. We consider the prospective research into the approach mentioned above should be connected with discovery of the local and the universal, the individual and the collective, the nationwide and the regional in the national artistic culture.

\section{תimepamypa}

1. Беспалова Ю. М. Биографические исследования в социологии культуры. Вестник Тюменского государственного университета. Социально-экономические и правовые исследования. 2004. № 4. С. 21 - 33.

2. Валевский А. Основания биографики. К., 1993. 109 с.

3. Голубович И. В. Биографрия: методология анализа в гуманитарном знании. Эпистемология \& Философия науки. 2012. T. XXXIII. №3. C. $84-97$.

4. Логунова Л. Ю. Биографический метод в исследовании личности: методология и архитектоника. Вестник Кемеровского государственного университета. Серия: Политические, социологические и экономические науки. 2016. № 1 . С. 17 - 23. 2010. 455

5. Менжулін В.І.Біографічний підхід в історико-філософському пізнанні : монографія. К : НаУКМА [Аграр Медіа Груп],

6. Попович О.В. Біографрія як феномен та об'єкт культури. Гуманітарний часопис. 2011. №2. С. 96 - 103. 
7. Росул Т. Біографія як соціокультурний вимір історії III Всеукр. наук. конф. "Мистецька освіта в європейському соціокультурному просторі XXI століття" (м. Мукачево, 13 - 14 березня 2014 р.). Мукачево, 2014. С. 113 - 115.

8. Соловьев Г. Е. Специфика биографического подхода в социальной работе с различными категориями населения Междунар. науч. конф. памяти профрессора Л. Н. Когана (г. Екатеринбург, 16 - 18 марта 2017 г.). Екатеринбург: УрФУ, 2017. С. $1544-1554$.

\title{
References
}

1. Bespalova, Yu. M. (2004). Biographical research in the sociology of culture. Socialjno-ekonomicheskije I pravovyje issledovanija, 4, 21-33 [in Russian].

2. Valevskij, A. (1993). The basis of biography. Kyiv [in Russian].

3. Golubovich, I. V. (2012). Biography: analysis methodology in the humanities. Epistemologia \& Filosofija nauki, XXXIII, 3, 84-97 [in Russian].

4. Logunova, L, Yu. (2016). Biographical method in the study of personality: methodology and architectonics. Vestnik Kemerovskogo gosudarstvennogo universiteta: Politicheskije, sociologicheskije i ekenomicheskije nauki, 1, 17-23 [in Russian].

5. Menzhulin, V. I. (2010). Biographical approach in historical and philosophical cognition. Kyiv: NaUKMA (Agrar Media Grup) [in Russian]. Ukrainian]

6. Popovich, O. V. (2011). Biography as a phenomenon and object of culture. Humanitarnyj chasopys, 2, 96-103 [in

7. Rosul, T. (2014). Biography as a socio-cultural dimension of history. III Vseukrajinsjka naukova konferencija "Mystecjka osvita v jevropejsjkomu sociokulturnomu prostori XXI stolittja" (pp. 113-115). Mukachevo [in Ukrainian].

8. Solovjov, G. J. (2017). Specificity of the biographical approach in social work with various categories of the population. Mezhdunarodnaja nauchnaja konferencyja pamjati professora L. N. Kogana (pp. 1544-1554). Ekaterinburg: UrFU [in Russian].

Стаття надійшла до редакції 23.12.2018р.

УДК $78.087 .68(477)$

Кириленко Яна Олексіївна

кандидат мистецтвознавства,

доцент кафедри вокально-хорового

мистецтва та музикознавства

Дніпропетровської академії

музики ім. М. Глінки

ORCID 0000-0001-9823-3897

kirilenko.yanina@gmail.com

\section{«КОНЦЕРТ» (ПАМ'ЯТІ МИКОЛИ ЛЕОНТОВИЧА) В. СТЕПУРКА ЯК ВТІЛЕННЯ МЕМОРІАЛЬНО-НЕОРЕЛІГІЙНОЇ МОДЕЛІ УКРАЇНСЬКОГО ХОРОВОГО КОНЦЕРТУ}

\begin{abstract}
Мета статті. У роботі досліджено меморіально-неорелігійну модель українського сучасного хорового концерту, як його жанрово-стильовий різновид розглянуто на прикладі найбільш репрезентативного твору, що її втілює, - хорового концерту В. Степурка «Концерт» (пам'яті Миколи Леонтовича). Методологія дослідження базується на поєднанні діалектичного, аналітичного, компаративного, структурно-функціонального методів, необхідних для порівняння жанрових моделей хорового концерту та характеристики його індивідуальних композиторсько-виконавських модифікацій. Наукова новизна полягає в тому, що вперше в українській науці виокремлено меморіально-неорелігійну модель українського сучасного хорового концерту, особливості якої презентовано на прикладі твору В. Степурка «Концерт» (пам'яті Миколи Леонтовича). Висновки. У «Концерті» (пам'яті Миколи Леонтовича) В. Степурка неорелігійна складова ґрунтується на циклічній моделі хорового концерту другої половини XVIII ст., а сама меморіально-неорелігійна модель інтерпретована в ліричному ключі. У творі виявлено поліпараметровість концертно-хорового діалогу, що межує зі стилізацією. Вибрані тексти, що базуються на фрагментах Книги Псалтир та Книги Еклезіястової, поєднані загальною темою покаяння (перша та друга частини), у третій частині на перший план виходить гомілетична складова. Яскравий національний первень, що йде від М. Леонтовича, робить «Концерт» В. Степурка затребуваним у сучасній хоровій практиці, де духовно-меморіальна репертуарна спрямованість виступає як одна з найбільш знакових.

Ключові слова: український хоровий концерт; меморіально-неорелігійна модель; концертно-хоровий стиль; концертно-хорова фрактура; хорова фресковість.
\end{abstract}

Кириленко Яна Алексеевна, кандидат искусствоведения, доцент кафедры вокально-хорового искусства и музыковедения Днепропетровской академии музыки им. М. Глинки

«Концерт» (памяти Николая Леонтовича) В. Степурко как воплощение мемориально-неорелигиозной модели украинского хорового концерта

Цель статьи. В работе исследовано мемориально-неорелигиознуюая модель украинского современного хорового концерта, как его жанрово-стилевая разновидность рассмотрена на примере наиболее репрезентативного произведения, ее олицетворяющего, - хорового концерта В. Степурко «Концерт» (памяти Николая Леонтовича). Методология исследования базируется на соединении диалектического, аналитического, компаративного, структурно-функционального методов, необходимых для сравнения жанровых моделей хорового концерта и характеристики его индивидуальных композиторскоисполнительских модификаций. Научная новизна заключается в том, что впервые в украинской науке выделено мемориальнонеорелигиозную модель украинского современного хорового концерта, особенности которой представлены на примере произведения В. Степурко «Концерт» (памяти Николая Леонтовича). Выводы. В «Концерте» (памяти Николая Леонтовича) В. Степурко неорелигиозная составляющая базируется на циклической модели хорового концерта второй половины XVIII В., a сама мемориально-неорелигиозная модель интерпретирована в лирическом ключе. В сочинении выявлена полипараметровость концертно-хорового диалога, граничащая со стилизацией. Избранные тексты, базирующиеся на фррагментах Книги Псалтирь и Книги Экклезиаста, объединены общей темой покаяния (первая и вторая части), в третьей части на первый план выходит гомилетическая составляющая. Яркое национальное начало, идущее от Н. Леонтовича, делает «Концерт» В. Степурко 